\title{
The Use of Phonograph Records in the Junior College
}

Miss Hauck, librarian of Blackburn College, Carlinville, Illinois, read this paper at the Junior College Libraries Section of the A.C.R.L. on June 24, in Boston.

$\mathrm{W}$ HEN I was asked to prepare a paper on the subject of the use of phonograph records in the junior college, it was suggested that the use made of records in the twenty-three junior colleges who had been recipients of Carnegie Music Sets might be the nucleus for the paper. These colleges were queried as to the use of their phonograph record collections, the means of encouraging that use, and the reaction of students to the program. Five of the librarians did not reply to my letter, and only ten of those replying gave any specific information. Hence, much of my paper will of necessity be quite general.

Judging from the replies received, only four colleges had record collections prior to the receipt of their Carnegie sets. I learned, to my surprise, that even though the ten original allocations of Carnegie Music Sets to junior colleges were an outgrowth of the Advisory Group on Junior -College Libraries, only six libraries have jurisdiction over the sets. Because the libraries do not have the proper housing facilities, the collections are being cared for by the departments of music.

In the schools where the departments of music administer the sets, the record collections are having regular use in the classes of theory and appreciation. Enrollment in appreciation classes has been reported doubled since these large anthologies of recorded music have been made available. Almost all the colleges have regular listening periods scheduled, and the entire student body is welcomed to enjoy the recordings. Students of musical instruments take advantage of the opportunity to check points of interpretation with the records of great artists. A violinist may take this means of practising with an orchestra. Ability to read scores is being developed among the nonmusic students. Regular concerts are being given, and these programs are often made up from student requests. Music instructors act as commentators for some of the programs. One college reported that only a small group of music students exhibited a continuous interest in the recordings. All the other schools felt that a large proportion of the students were regular listeners. Under the department of music supervision there is little developing of the original Carnegie collections except in the field of music.

Some of the junior colleges, particularly those in which the record collections are under library supervision, are extending the use of their collections far beyond the field of music. It is this phase of the use of records in the junior colleges that I wish to discuss in more detail. I shall approach the subject by telling you of 
the use of the record collection in the Blackburn College Library, because I know more about it than any other.

The Blackburn collection antedates by several years the receipt of the Carnegie Music Set. The collection had its beginning outside of the library in the departments of English, French, German, and Spanish. Several language series had been purchased for class use, and the head of the department of English had secured some records to be used in the teaching of modern poetry. Her personal collection of recordings of early English music and Shakespearian songs inspired us to request that a Carnegie Music Set be allocated to Blackburn College.

Before the arrival of the Carnegie set in November 1939, plans were made to house it in a room in the library, placing it entirely under the supervision of the library. The stray records over the campus were collected; the English instructor donated the recordings of poetry and English songs; and the library music room was inaugurated, operating under a system of voluntary student proctors. Immediately, student interest reached a surprising peak. The students approved wholeheartedly the collection of Carnegie records, but they soon compiled a list of suggestions for additions. The faculty likewise had suggestions to offer.

We began to peruse the record catalogs and to follow the reviews of current releases. We bought many of the records which the students requested. I might say in passing that the requests of Blackburn students for certain compositions were almost identical with the requests of Mars Hill College students. About half of our purchases have been made with the hope of their having classroom use. For example, Maurice Evans' albums of $\mathrm{Ham}$ - let and Richard II have been enjoyed in both the freshman English and English literature classes. We considered the Orson Welles' recordings of the Shakespearian plays, but the students' reaction of amusement caused us to decide against them. Incidentally, the Welles' recordings might be very valuable for high school or junior high school literature work.

More and more of the modern poets are making recordings of their poems, and we have purchased almost all the available recordings for use in the modern poetry unit of the freshman English course. In our collection the following modern poets are represented: De La Mare, Frost, Lindsay, Hillyer, Holmes, Auden, and Sandburg. We also have readings from the older poets such as Blake, Milton, Shakespeare, and Wordsworth.

\section{Records of Plays}

Records furnish supplementary material for the drama unit of the freshman course. Oscar Wilde's Importance of Being Earnest is taught, and the Gielgud cut from the play affords lively entertainment. James Weldon Johnson's reading of The Creation ties up with the teaching of Green Pastures, as also do the spirituals from the Carnegie collection. The classes in religion have likewise made use of the spirituals and the Johnson recordings.

Hardy's Return of the Native is, as is the case in most schools, another unit in the freshman course. One class hour is given to listening to Sir Edmund Gosse's tribute to Thomas Hardy. The playing of this recording serves a dual purpose in that a note taking exercise is made of it. After discussion of the subject of note taking, a check is made by the use of the Gosse lecture, to see whether the students are actually able to take intelligent notes. 
During the past school year as interest in the use of records developed, three instructors have used some of their departmental library appropriations for the purchase of records. The German instructor considers the complete recording of Mozart's The Magic Flute to be one of the finest examples of German diction. These Mozart albums were purchased, the libretto dittoed, and the students of German have spent hours in the classroom and in the library music room listening to The Magic Flute. The German Lieder of the original Carnegie set are also frequently used in the German classes. One cannot deny that this is a pleasant and painless bit of ear training.

\section{Recordings in French}

A number of foreign recordings in French have been selected. Scenes from Molière, Corneille, and Rostand offer excellent opportunity for ear training. There is a new recording of a dramatization of Guy de Maupassant's The Necklace to be played after the French classes have read the story. A Sacha Guitry album is one of the most delightful bits representative of modern French culture which one could hope to find. The musical settings of this album add much to the listener's enjoyment. We have not been above stooping to swing, surprisingly enough. Because of the clarity of diction, the recent recording of the popular selection Les enfants s'ennuient le dimanche has been added to the collection. Students other than those of the French classes have learned of this record, and the librarian has had to refuse requests to borrow the record for the weekly "teasers," fifty-minute dances to recorded music.

The department of English has been buying regularly anything thought to be useful for class instruction. Songs, whose lyrics have been written by Blake, Thomas Moore, Matthew Arnold, Tagore, Wordsworth, or have been taken from the Rubaiyat, are used in the English literature classes. The head of the department planned an interesting feature, a series of music-literature programs, which utilized every possible record in our collection, and which were given not as part of the class work, but as entertainment for the entire campus. There were programs with titles such as these: Modern Poetry; The Nineteenth Century; Gilbert and Sullivan; Hamlet; Richard II; Romeo and Juliet; Midsummer Night's Dream; and the Merry $W$ ives of $W$ indsor; Shakespearean Songs; Sixteenth and Seventeenth Century English Songs; American, English, Gaelic, and Welsh Folk Songs; and there were longer programs for the playing of the entire recordings of Wagner's Tristan und Isolde, Gounod's Faust, and Berlioz's The Damnation of Faust.

\section{Phonographs}

Our records may be played on a small phonograph which has been provided for classroom use, or an instructor may bring his class to the library music room, where the excellent Carnegie instrument affords magnificent reproduction for all types of records. Instructors are urged to make use of the better machine, and to have their students enjoy the pleasant, informal atmosphere of the music room.

At Blackburn we have no department of music, and I think the students have a greater sense of appreciation and gratitude because they are lacking the advantage of formal musical education. The members of our college choir have been ardent listeners to all the choral selections, and the interest of the entire student body 
has been phenomenal. All the operas, symphonies, concertos, and the Messiah have been played many times in their entirety. Any Sunday afternoon concert or daily chapel concert has been received with the greatest of approval.

One of our young English instructors, a former Rhodes scholar, owned an extensive collection of records, which he had obtained abroad. The majority of his records were of early music and quite rare. This instructor also had an unusual collection of art reproductions. Both collections were used in class, and he also gave a series of lectures synchronizing the history of music and art. For example, while presenting early Gothic art, music of Léonin was played, or while discussing the transition from the Gothic to the Renaissance, selections from Josquin des Prés were offered, or making a great jump, while showing a Renoir, Debussy or Ravel supplied the musical setting. A similar idea has been recently developed in the book entitled Music in History, by Howard D. McKinney and W. R. Anderson.

Now I shall tell you what is being done with record collections in some of the other junior colleges. Undoubtedly you have read in a recent issue of the Junior College Journal the article about the correlating of music with history, literature, and the visual arts at Green Mountain College. Two colleges, Stephens and Frances Shimer, are making extensive use of their record collections in their humanities survey course. In most schools the Elizabethan songs are played in literature classes. Club groups are grateful for the opportunity of having records for their programs. At Mars Hill College, a music identification contest was sponsored and voted a success. On many campuses records are supplying the musical settings for dramatic productions. Colleges are exerting wider influence in their communities by sharing their recordings with those outside of the colleges. Civic clubs, public school classes, and private groups are being given the pleasure of using the college collections. The recently published pamphlet, Memorandum on the Use of Art and Music Study Material, prepared by Florence Anderson for the Carnegie Corporation of New York, tells of this enriching influence observed in the colleges and universities who have been the fortunate recipients of music sets.

I had expected that some information regarding the use of records in speech classes would be forthcoming, but no librarian mentioned that aspect. At Blackburn we offer no work in speech. I feel certain, though, that records do have, or could have, great use in this field.

\section{Cataloging}

A word about the cataloging of records at Blackburn. The Carnegie sets are arranged in a simple but satisfactory manner, and the cataloging by composer, title, medium, and form serves perfectly. We have followed the Carnegie system, adding the form division "Poetry and Readings" under which we have placed all our miscellaneous group of drama, poetry, et cetera. To the label of the composer file we have added the word "author," making it possible to file the author entries therein. We also have made a shelflist of the collection because of the aid it would be in checking. Checking the collection is a necessary procedure because our students have such free access to the collection.

At Francis Shimer the original collection of records was classified according to the scheme worked out and used at Smith College, and nothing has yet been done 
about combining the older collection with the Carnegie set, but at some future date the older records will probably be reclassed according to the simpler scheme. North Park's original collection is also being kept separate from the Carnegie set.

In most of the junior colleges, the records are not being generally circulated to the students. The departments of music fear that records might not be available when needed for class. If the records are not circulated, it is possible to control the type needle used in playing them, thus, perhaps, prolonging the life of the collection. Students of some schools do not have portable phonographs on which to play the records, and when a school does own a fine phonograph, it seems much better to have the records played under the best circumstances. Perhaps the ideal situation is to provide a listening room which is open all the time as is done at Stephens and Blackburn. All the other colleges have made the records available for only a few hours each day.

\section{Aids to a Project}

For the college which lacks the advantage of a large anthology of recorded music like a Carnegie set, but which wishes to embark on a program involving the use of phonograph records, there are valuable aids to the project. The record shops are publishing lists of special interest to college instructors and librarians. Then books on the subject are being published. Such organizations as the National Council of Teachers of English are sponsoring recordings. The Division of Museum Extension of the Museum of Fine Arts of Boston is publishing a series of portfolios of plates on various subjects. I have used two of these, one called Elizabethan England, and the other the French Renaissance. Accompanying these portfolios there are excellently written texts, which conclude with lists of records illustrating the music of the period under discussion. What better aid could one have for a history, literature, or humanities course?

Several of the junior college librarians have expressed the hope that in the future their libraries might have record collections and develop that aspect of library service just as the service of books has been developed. I cannot help thinking that there are great possibilities in this field, and that in a short time, with the encouragement of the librarians, college instructors will more and more utilize the vitalizing effect of various types of phonograph records in class instruction. 